Old Dominion University

ODU Digital Commons

\title{
Eddy-Driven Transport of Particulate Organic Carbon-Rich Coastal Water Off the West Antarctic Peninsula
}

\author{
Renato M. Castelao \\ Michael S. Dinniman \\ Old Dominion University, msd@ccpo.odu.edu \\ Caitlin M. Amos \\ John M. Klinck \\ Old Dominion University, jklinck@odu.edu \\ Patricia M. Medeiros
}

Follow this and additional works at: https://digitalcommons.odu.edu/ccpo_pubs

Part of the Climate Commons

\section{Original Publication Citation}

Castelao, R. M., Dinniman, M. S., Amos, C. M., Klinck, J. M., \& Medeiros, P. M. (2021). Eddy-driven transport of particulate organic carbon-rich coastal water off the West Antarctic Peninsula. Journal of Geophysical Research: Oceans, 126(3), 1-13, Article e2020JC016791. https://doi.org/10.1029/ 2020JC016791 


\section{JGR Oceans}

\section{RESEARCH ARTICLE \\ 10.1029/2020JC016791 \\ Key Points: \\ - Cyclonic eddies generated near the coast off the West Antarctic Peninsula often propagate offshore \\ - Those eddies can trap coastal water rich in particulate organic carbon (POC) in their interior, resulting in POC enrichment in offshore waters off the Peninsula \\ - Model results suggest that half of the eddy-driven volume transport of coastal water is due to small eddies that are missed by altimetry}

Correspondence to:

R. M. Castelao,

castelao@uga.edu

Citation:

Castelao, R. M., Dinniman, M. S., Amos, C. M., Klinck, J. M., \& Medeiros, P. M. (2021). Eddy-driven transport of particulate organic carbon-rich coastal water off the West Antarctic Peninsula. Journal of Geophysical Research: Oceans, 126, e2020JC016791. https:// doi.org/10.1029/2020JC016791

Received 12 SEP 2020 Accepted 5 MAR 2021
(C) 2021. American Geophysical Union. All Rights Reserved.

\section{Eddy-Driven Transport of Particulate Organic Carbon- Rich Coastal Water Off the West Antarctic Peninsula}

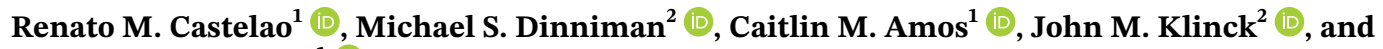 \\ Patricia M. Medeiros ${ }^{1}$ (i) \\ ${ }^{1}$ Department of Marine Sciences, University of Georgia, Athens, GA, USA, ${ }^{2}$ Center for Coastal Physical Oceanography, \\ Old Dominion University, Norfolk, VA, USA
}

\begin{abstract}
The Southern Ocean is characterized by high eddy activity and high particulate organic carbon (POC) content during summer, especially near Antarctica. Because it encircles the globe, it provides a pathway for inter-basin exchange. Here, we use satellite observations and a high-resolution ocean model to quantify offshore transport of coastal water rich in POC off the West Antarctic Peninsula. We show that nonlinear cyclonic eddies generated near the coast often trap coastal water rich in POC during formation before propagating offshore. As a result, cyclones found offshore that were generated near the coast have on average higher POC content in their interior than cyclones generated locally offshore. This results in a POC enrichment of $5.7 \pm 3.0 \mathrm{Gg} \mathrm{C}_{\text {year }}{ }^{-1}$ in offshore waters off the Peninsula. Actual POC enrichment is likely substantially larger, since about half of the volume transport of coastal water is driven by small eddies that are missed by observations.
\end{abstract}

Plain Language Summary Coastal waters off Antarctica during summer are generally highly productive, being characterized by high concentrations of particulate organic carbon (POC). Mechanisms driving offshore transport of coastal water are important because they contribute to spreading that organic carbon over large areas of the Southern Ocean. Here, we combine satellite observations and model results to show that when cyclonic eddies are generated near the coast, they often trap coastal water rich in POC in their interior. As those eddies propagate offshore, they carry that signature with them, resulting in POC enrichment in offshore areas. Model results indicate that small eddies, which are generally missed by satellite altimetry, can account for half of the eddy-driven volume transport of coastal water.

\section{Introduction}

The Southern Ocean plays a disproportionally large role in the global carbon cycle (McNeil et al., 2007; Metzl et al., 1999; Takahashi et al., 2002). The Southern Ocean is also unique because it encircles the globe, providing a pathway for exchange of water, carbon, and other properties between the different ocean basins. Efforts to quantify particulate organic carbon (POC) distribution on large scales are often hampered by the sparseness of in situ data, both at spatial and at temporal scales. Studies have shown that POC concentration is often well correlated with band ratios of spectral remote-sensing reflectance (e.g., Stramski et al., 1999). This allowed for the development of satellite algorithms for estimating POC in the upper ocean from ocean color (Gardner et al., 2006; Pabi \& Arrigo, 2006; Stramski et al., 2008). Using such algorithms, Allison et al. (2010) showed that the region close to Antarctica is characterized by high POC during the austral summer, providing a dominant contribution to the accumulation of POC within the Southern Ocean during the productive period of the season.

Mechanisms transporting coastal water rich in POC offshore off Antarctica are important because they contribute to spreading that biogeochemical signature over a larger area of the Southern Ocean. This allows for coastal production to influence biogeochemical processes in the open ocean, in areas away from production sites near the coast. One process likely to contribute to the offshore transport is nonlinear mesoscale eddies. Oceanic mesoscale variability occurs primarily as nonlinear eddies (eddies with rotational speed exceeding their translation speed; Chelton et al., 2007; Chelton, Schlax, \& Samelson, 2011), which can trap water in their interior and transport properties such as heat, salt, nutrients, and carbon along their trajectories (Samelson \& Wiggins, 2006). Even though the entrapment mechanism is not perfect (i.e., some material can leak from the eddy interior; de Steur et al., 2004), eddies have been shown to transport materials in various regions 


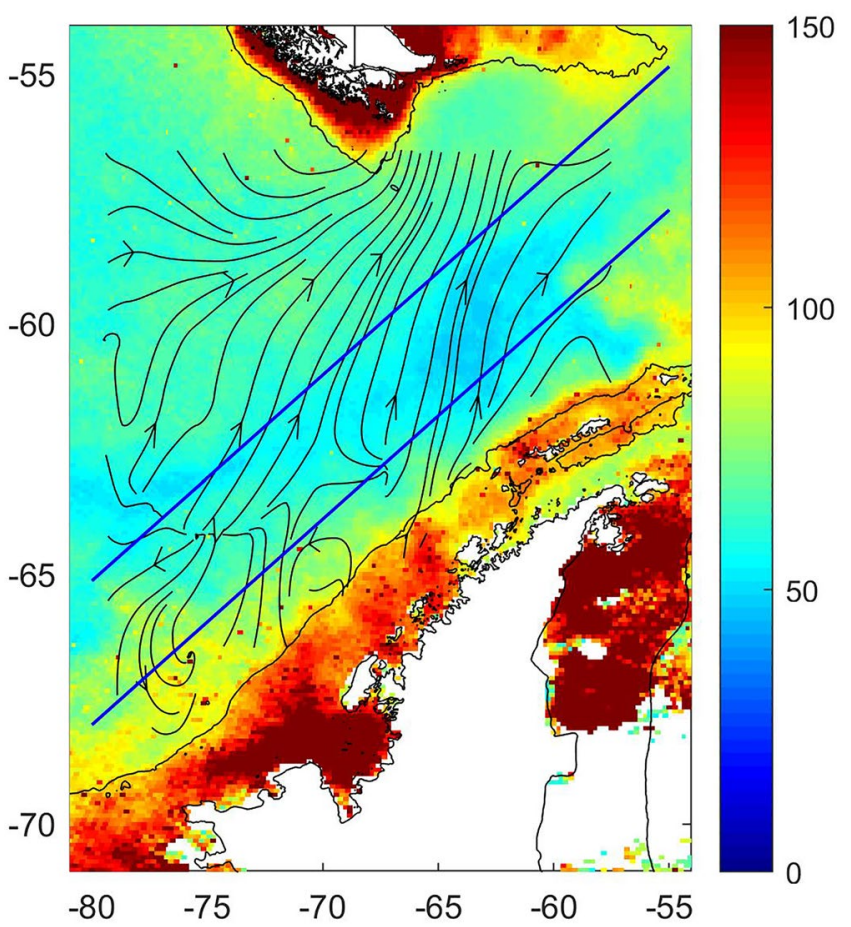

Figure 1. Average surface POC concentration $\left(\mathrm{mg} \mathrm{m}^{-3}\right)$ during austral summer from SeaWiFs. Black arrows show mean direction of propagation of cyclonic eddies from altimetry. Blue lines delineate offshore region used for analyses. Thin black contour is 1,000 $\mathrm{m}$ isobath. POC, particulate organic carbon; SeaWiFs, Sea-Viewing Wide Field-of-View Sensor. of the ocean (Amos et al., 2019; Gaube et al., 2014; Lehahn et al., 2011), resulting in significant cross-isobath flows (Castelao, 2014; Castelao \& He, 2013; Chaigneau et al., 2011; Nagai et al., 2015) and affecting physical (Gaube et al., 2019) and biogeochemical (Chenillat et al., 2016) processes. The Southern Ocean is characterized by strong eddy activity (Kahru et al., 2007; Patara et al., 2016), and eddies around Antarctica are particularly effective in trapping material in their interior as they propagate (Frenger et al., 2015). Along the Antarctic continental shelf, small (radii of 5-10 km) eddies are important in transporting offshore heat onto and across the shelf in many locations (Stewart et al., 2018), especially along the West Antarctic Peninsula (WAP) (Couto et al., 2017; Martinson \& McKee, 2012; McKee et al., 2019; Moffat et al., 2009). To balance the onshore volume transport, offshore transport may be driven by several mechanisms, including possibly by eddies, with small eddies $(\sim 6 \mathrm{~km})$ shed from the shelf and larger eddies (radii of 50-60 km) detaching from topographic features along the slope (Brearley et al., 2019).

Here, we used satellite-derived sea level anomalies and ocean color to quantify the importance of nonlinear eddies in transporting coastal water rich in POC offshore off the WAP based on observations. A key limitation for studies in high-latitude regions is the inability of low-resolution altimetry data to resolve small-scale eddies (Chelton, Schlax, \& Samelson, 2011). We quantified this limitation by comparing observational results with outputs from a high resolution, submesoscale permitting ocean model simulation.

\section{Methods}

POC concentrations were estimated from observations of remote-sensing reflectance from SeaWiFs (Sea-Viewing Wide Field-of-View Sensor) at $9 \mathrm{~km}$ resolution from September 1997 to December 2010 using the algorithm of Allison et al. (2010) (Figure 1). The $9 \mathrm{~km}$ data product was used to better match the resolution of altimetry observations (see below). To reduce the influence of cloud coverage, data were averaged at a 7 days interval. Data off the WAP are generally not available from May to August due to sea ice cover. Data availability increases in September/ October, is highest from November to March, and generally decreases sharply in April. In situ data used by Allison et al. (2010) to develop their algorithm were restricted to open water stations, avoiding the optically complex coastal environments that often present challenges for ocean color algorithms. Here, satellite observations were compared to historic in situ POC data from coastal regions off the WAP collected during research cruises from 1991 to 2018 as part of the Palmer Long Term Ecological Research (Palmer-LTER) program. In situ samples are available from November to March, although most samples have been collected in January. In situ samples were processed according to Palmer LTER standard protocols (collected on combusted $0.7 \mu \mathrm{m}$ glass fiber filters and analyzed via combustion using a CHNS/O Analyzer; Luria et al., 2017), and were downloaded from the Palmer LTER data portal. Satellite observations were interpolated in time and in space to match the location and time of the in situ data. The comparison revealed that 7 days-averaged satellite concentrations are significantly correlated with in situ POC in coastal areas (Figure 2), indicating that the algorithm, although calibrated for offshore regions, provides useful information near the coast. Satellite-derived concentrations are smaller than in situ POC for concentrations larger than $\sim 80 \mathrm{mg} \mathrm{m}^{-3}$ and slightly larger for concentrations smaller than that threshold. There is also substantial scatter in the comparison, with larger variability observed in the in situ coastal data compared to satellite observations. This is expected since each satellite pixel spans a much larger area than the in situ point measurements, in addition to representing an average of 7 days, rather than an instantaneous measurement. As such, satellite observations cannot represent small/short scale variability associated with patchiness in POC distribution. This is especially important in coastal areas, where scales of variability are reduced due to the smaller Rossby radius. Water column POC integrated from the surface to $100 \mathrm{~m}$ depth $\left(\mathrm{POC}_{100}\right)$ has been shown to be 

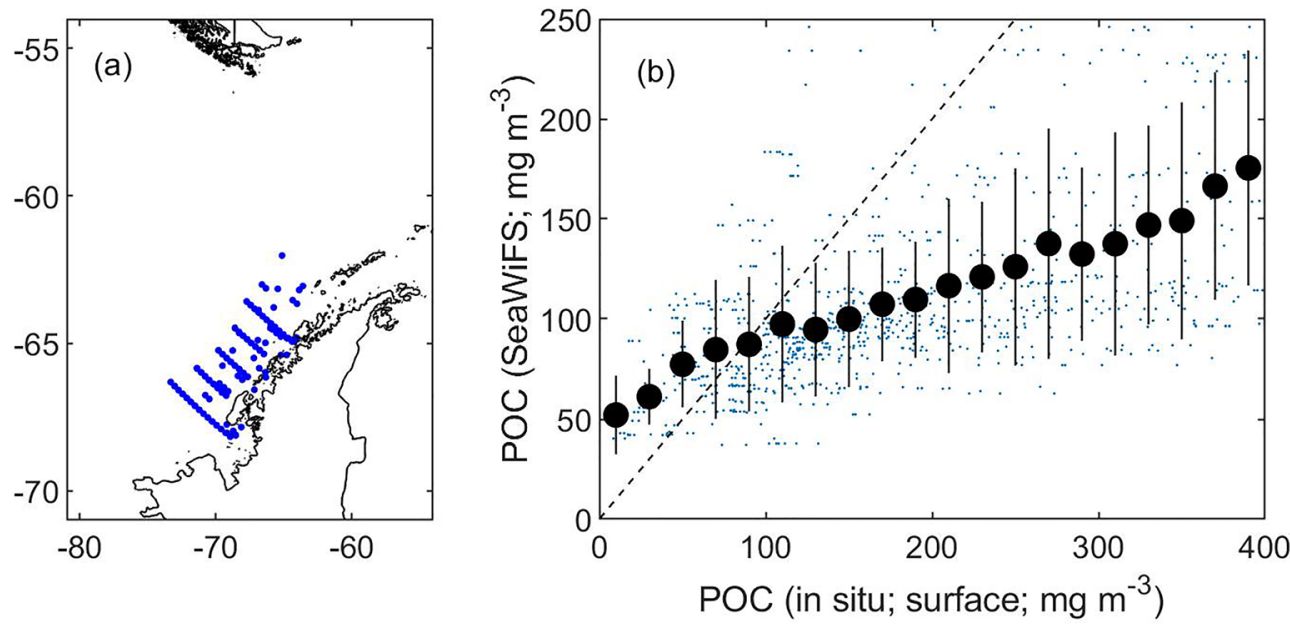

Figure 2. (a) Location of in situ surface observations of POC concentration from the Palmer LTER project. (b) Binned scatterplot of in situ surface POC concentrations from the Palmer LTER and satellite-derived surface POC concentration (based on 7 days averages) using the algorithm of Allison et al. (2010). Black circles and vertical bars are mean \pm 1 standard deviation for each bin. Individual data are shown by small blue dots. The 1:1 line (dashed) is shown for reference. Palmer LTER data span the entire SeaWiFS period. LTER, Long Term Ecological Research; POC, particulate organic carbon.

highly correlated with surface concentrations obtained from several cruises in the Southern Ocean, including off the WAP $\left(r^{2}=0.91\right.$; Allison et al., 2010). Using this relationship, Allison et al. (2010) developed an algorithm $\left(\mathrm{POC}_{100}\left(\mathrm{~g} \mathrm{~m}^{-2}\right)=0.04737( \pm 0.00141) \times\right.$ surface POC $\left.\left(\mathrm{mg} \mathrm{m}^{-3}\right)+2.16672( \pm 0.22816)\right)$ allowing for POC content in the top $100 \mathrm{~m}$ to be estimated from satellite data.

Mesoscale eddies' characteristics and location were obtained from an existing global dataset from altimetry observations (Chelton, Schlax, \& Samelson, 2011; Schlax \& Chelton, 2016). Features with e-folding scales smaller than $\sim 0.4^{\circ}$ are generally not well resolved in the data (Chelton, Schlax, \& Samelson, 2011). In the data set, eddy radius is defined as the radius of a circle whose area is equal to that enclosed by the contour of maximum circum-average speed around the eddy. The amplitude is defined as the difference between the maximum (for anticyclones) or minimum (for cyclones) sea surface height within the eddy and the average height around the outermost closed contour of sea surface height that defines the eddy perimeter (Chelton, Schlax, \& Samelson, 2011). All cyclonic and anticyclonic eddies observed offshore off the WAP were identified and separated into two groups, one with eddies generated locally offshore (between the two blue lines in Figure 1) and another with eddies generated close to the coast (to the south of the southernmost blue line in Figure 1; most of these eddies are generated offshore of the shelfbreak) that propagated offshore. Since POC is used here as a tracer of coastal water, a distance larger than the average width of the coastal band of high POC concentrations was chosen to distinguish between coastal and offshore water (boundary identified by the southernmost blue line in Figure 1), as in Amos et al. (2019). The POC and POC 100 anomalies associated with each eddy were extracted following Amos et al. (2019). Briefly, we began by spatially highpass filtering (Chelton et al., 2004; Schlax \& Chelton, 2016) the POC fields from SeaWiFS to remove largescale patterns not related to mesoscale variability. The resulting anomalies (with respect to the large-scale background field) in POC concentration and in the integrated POC content in the top $100 \mathrm{~m}\left(\mathrm{POC}_{100}\right)$ within 2-by-2 eddy radii from the eddy center were extracted for all eddies identified in the dataset of mesoscale eddies used here (Chelton, Schlax, \& Samelson, 2011). In each case, we normalized the distance from the eddy center by the eddy radius, a procedure often used to allow for comparisons of eddies of different radii (e.g., Chelton, Gaube, et al., 2011; Gaube et al., 2013, 2014). Only eddies with at least $90 \%$ coverage for POC observations (ice- and cloud-free pixels) within one eddy radius and $75 \%$ within two radii were used. To remove noise and other mesoscale variability that were not related to the eddy, a 2D Gaussian function was fitted to the resulting POC and $\mathrm{POC}_{100}$ anomaly fields (Yuan \& Castelao, 2017), consistent with the average eddy shape (Chelton, Schlax, \& Samelson, 2011). Repeating the analyses without the Gaussian fit produced results that are quantitatively similar to those presented here, although visual inspection of the anomalies 

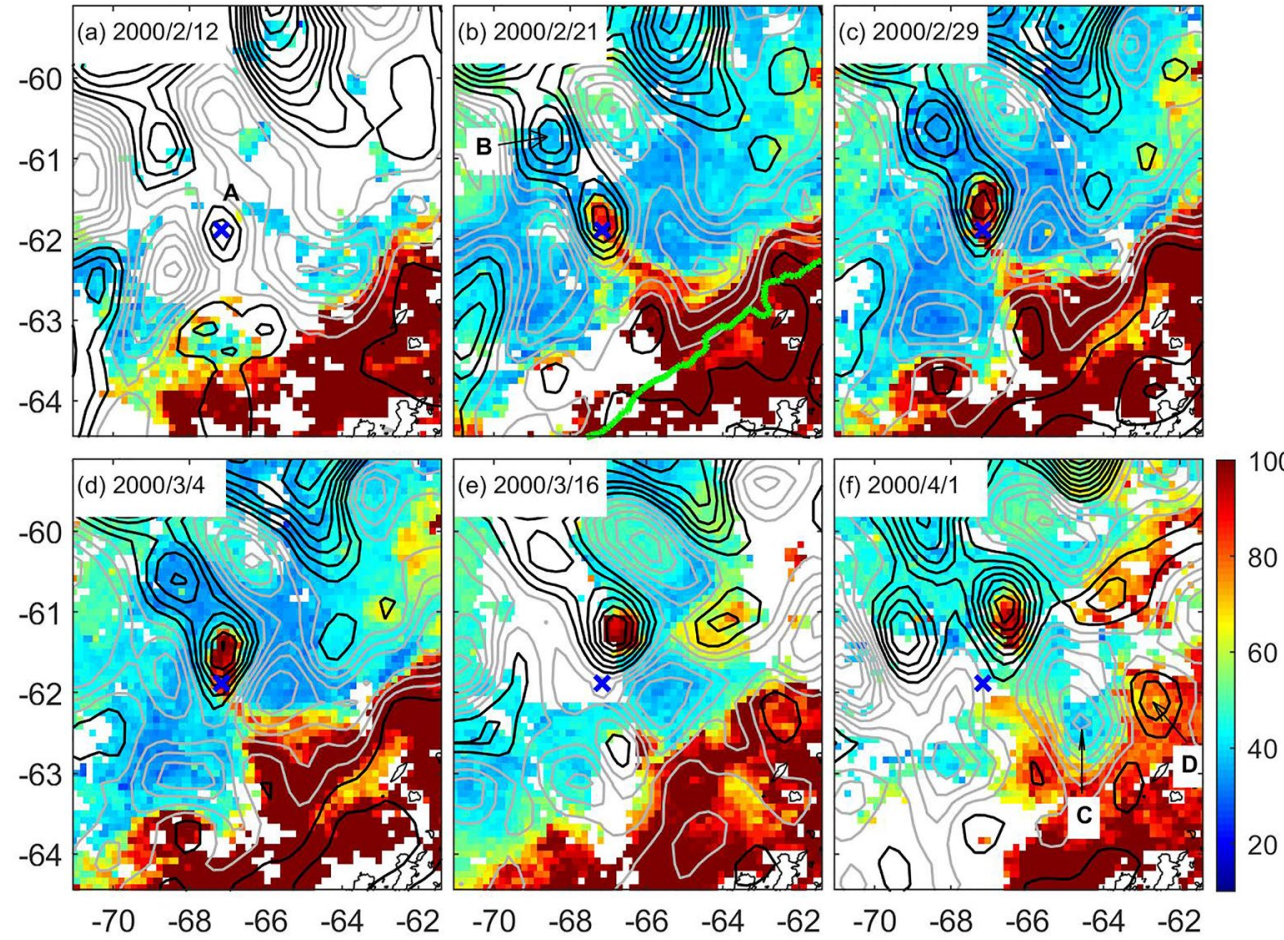

Figure 3. Surface POC concentration (colors; 7 days composites, $\mathrm{mg} \mathrm{m}^{-3}$ ) and sea level anomalies (contours, $3 \mathrm{~cm}$ interval) from satellite observations off the WAP. Black (gray) contours are negative (positive). Blue cross shows position of cyclone A on February 12. Thick green contour in (b) is 1,000 $\mathrm{m}$ isobath. A and D indicate cyclonic eddies that potentially trapped coastal water rich in POC in their interior, while cyclonic eddy B was generated far from the coast. $\mathrm{C}$ indicates an anticyclonic eddy. POC, particulate organic carbon; WAP, West Antarctic Peninsula.

revealed several mesoscale features that are likely not related to the eddies, especially around the edges of the 2-by-2 eddy radii boxes. Using the Gaussian fit allowed for the eddy signature to be isolated from those other mesoscale features (Amos et al., 2019).

Once the $\mathrm{POC}$ and $\mathrm{POC}_{100}$ signatures associated with the eddies were isolated, they were used to build composites of $\mathrm{POC}$ and $\mathrm{POC}_{100}$ anomalies for both cyclonic and anticyclonic eddies according to their location, generation site, and amplitude. We built separate composites for eddies found offshore (region inside blue lines in Figure 1) that were generated locally offshore and for those that were generated near the coast that propagated offshore. The composites were also built separately for eddies of different amplitudes, since it is possible that eddies of different amplitudes have different characteristics (e.g., differences in strength of vertical circulation in their interior). The composites were then used to compute the POC enrichment in the top $100 \mathrm{~m}$ in offshore waters due to eddy-driven transport across the southernmost transect in Figure 1 as

$$
\text { POC enrichment }\left(\text { Gg year }^{-1}\right)=\Delta\left(\text { POC }_{100}\right) \times \text { eddy area } \times N
$$

where $\Delta\left(\mathrm{POC}_{100}\right)$ is the difference in $\mathrm{POC}_{100}$ inside cyclones or anticyclones found offshore that were generated near the coast and those generated offshore for each amplitude bin, and $N$ is the number of eddies of either polarity that were generated each year near the coast and propagated offshore for each amplitude bin. The POC enrichment was calculated by summing over the various amplitude bins. The assumption is that while POC concentration inside an eddy generated locally offshore will be influenced by processes occurring within the eddy (e.g., upwelling), POC concentration inside an eddy that was generated near the coast and moved offshore will be additionally influenced by the trapping of coastal water rich in POC in the eddy interior (e.g., cyclone A in Figure 3). Therefore, the difference in POC concentration between those eddies (of similar amplitude) provides a measure of POC enrichment offshore due to the trapping of coastal water (e.g., trapping of POC rich waters, local production through utilization of nutrients trapped near the coast 
during formation). Uncertainty in the POC enrichment estimate was obtained by propagating uncertainties in eddy radius, in the number of eddies generated near the coast that propagate offshore in each year, in the integrated POC anomaly associated with eddies in each amplitude bin, and in the slope and intercept for the linear fit between surface and vertically integrated POC concentrations (given in Allison et al., 2010). Additional details of the method are described in Amos et al. (2019).

To investigate the potential importance of small-scale eddies that are missed by altimetry observations, we used a circulation model that was previously implemented for the WAP and described in detail by Graham et al. (2016). The model uses the Regional Ocean Modeling System (ROMS) (Haidvogel et al., 2008), which is a primitive equation ocean circulation model with a free surface and a terrain-following vertical coordinate. The configuration used for the WAP has $1.5 \mathrm{~km}$ horizontal resolution and 24 variable-thickness vertical layers that are concentrated toward the top and bottom surfaces. The $1.5 \mathrm{~km}$ resolution model has been shown to simulate well small scale $(\sim 5-10 \mathrm{~km})$ eddy heat transport onto the WAP continental shelf (Graham et al., 2016) and larger scale eddy volume transport off the WAP continental shelf/slope (Brearley et al., 2019). It includes a dynamic sea ice model (Budgell, 2005) and simulates mechanical and thermodynamic interactions between the floating ice shelves in the model domain and the water cavity underneath (Dinniman et al., 2011; Holland \& Jenkins, 1999). Model bathymetry is from the Bedmap2 database (Fretwell et al., 2013). Atmospheric forcing is from archived forecasts from the Antarctic Mesoscale Prediction System (Powers et al., 2012) covering the period 2006 through 2012. Laplacian horizontal viscosity is used with a small value $\left(0.1 \mathrm{~m}^{2} \mathrm{~s}^{-1}\right)$ such that the damping time scale due to added numerical viscosity (Haidvogel \& Beckmann, 1999) for the smallest eddies studied here (11 km) is much greater (4 years) than the period over which any of the eddies are tracked. For further details on the model forcing (including lateral open boundaries), see Graham et al. (2016). An explicit biogeochemical model is not used in the current implementation.

A visualization of model eddy transport away from the WAP was created by using a Eulerian tracer in the circulation model. At a given time step during the model integration a passive tracer with a default value of 1.0 was placed throughout the entire vertical water column. The tracer was released on January 25,2009 in this example, in all grid points shoreward of the model $0.08 \mathrm{~m}$ sea surface elevation anomaly contour (with respect to the long term mean over the model domain) along the WAP. The threshold of $0.08 \mathrm{~m}$ was chosen because at that time step it delineated the front separating coastal and offshore waters (see Figure 6). This tracer was then allowed to freely advect and diffuse within the model domain based on the modeled circulation for the duration of the simulation.

Lastly, we also provided a crude estimate of the fraction of volume transport by eddies of different radii based on observations and model results. Volume transport was computed as in Amos et al. (2019) as (eddy area $\times D \times N \times$ trapping efficiency)/T, where $N$ is the number of eddies generated near the coast that moved offshore each year, $\mathrm{T}$ is the number of seconds in 1 year, and $D$ is the thickness of the layer with trapped fluid. By focusing on a surface layer $D$ (say, top 100, or top $200 \mathrm{~m}$ ) thinner than the trapping depth of eddies (eddy signatures in the Southern Ocean extend down to 2,000 $\mathrm{m}$ on average, and they are likely to trap fluid in the top 1,000 m; Frenger et al., 2015), a constant value for $D$ could be used for eddies of different radii. For simplicity, we also assumed that the trapping efficiency (fraction of fluid actually trapped by eddies) is the same for eddies of different radii. Previous studies in other systems have shown that trapping efficiencies may vary between eddies, but differences are generally small ( 10\%; Amos et al., 2019). These simplifications precluded quantitative estimates of transport. However, they allowed for identifying the relative importance of eddies of different sizes on the overall eddy-driven transport on the surface layer of thickness $D$, with results being independent of the values chosen for trapping depth and efficiency. This calculation allowed us to estimate if small scale eddies that are resolved in the high-resolution model simulations but that are missed in the lower resolution altimetry data can make an important contribution to offshore transport.

\section{Results}

The coastal region off the WAP is characterized by high POC content during the austral summer (Figure 1), with concentrations decreasing sharply offshore of $\sim 200 \mathrm{~km}$ from the coast. The region is also characterized by strong mesoscale eddy activity (Kahru et al., 2007; Frenger et al., 2013, 2015). Analyses of the long-term 
altimetry record indicated that eddies between the Peninsula and the tip of South America generally propagate northeastward (Figure 1), likely influenced by the strong mean flow of the Antarctic Circumpolar Current (ACC) (Frenger et al., 2015). Most of those eddies are nonlinear, indicating that they can theoretically trap and transport fluid in their interior as they propagate (Chelton, Schlax, \& Samelson, 2011; Flierl, 1981). Since coastal waters during summer are rich in POC, eddies generated near the coast off the Peninsula have the potential of trapping and transporting POC (and any other material contained in the water) offshore toward the ACC.

An example of offshore transport of coastal water rich in POC by a mesoscale eddy is shown in Figure 3. Features observed in the POC data generally matched well with mesoscale features resolved by the comparatively lower resolution sea level anomaly observations from altimetry. Consistent with the average POC distribution, a strong gradient in POC concentrations was observed, with high content restricted to coastal waters although extending beyond the $1,000 \mathrm{~m}$ isobath into slope waters. A cyclonic eddy was formed in early February (cyclone A in Figure 3a), characterized by high POC content in its interior (Figure 3b). Note that cyclone B located farther offshore had low POC content on February 21, even though it had approximately the same radius and amplitude as cyclone A. This is consistent with high POC content inside cyclone A being due to coastal water being trapped in its interior, rather than to local production. As cyclone A moved northeastward over the next several weeks (Figures 3c-3f), the patch of high POC water also moved offshore, presumably trapped in the eddy's interior. Cyclone A was only slightly larger than the area with high POC on February 21. As the eddy moved offshore and grew with time (Samelson et al., 2014), however, it became substantially larger than the area with high POC by April 1. This is also consistent with the high POC content inside the eddy being related to trapping and offshore transport of coastal water. POC content on April 1 also matched the spatial scales of eddies C and D (Figure 3f). Cyclone D, whose formation can be seen in the previous panels (Figures $3 \mathrm{~d}$ and $3 \mathrm{e}$ ), propagated northeastward in the following days. Although no POC data are available for that time, it is likely that water rich in POC was transported offshore within cyclone D, much the same way that cyclone A contributed to POC enrichment offshore.

To identify the effects of the offshore propagation of nonlinear eddies on POC distribution away from the coast, we quantified the POC anomaly associated with all eddies observed in offshore waters off the Peninsula. We compared the POC anomalies for eddies found in offshore waters that were generated locally offshore (between the blue lines in Figure 1) with the anomalies for eddies found in offshore waters but that were generated near the coast (to the south of the southernmost blue line in Figure 1). Most of these coastal eddies that were captured by altimetry were formed off the shelf offshore of the 1,000 $\mathrm{m}$ isobath, where averaged POC concentrations are reduced (Figure 1). However, the front separating coastal water rich in POC and offshore waters is often situated offshore of the $1,000 \mathrm{~m}$ isobath in instantaneous measurements (e.g., Figure 3b). The analysis revealed that, for a given amplitude, cyclonic eddies found offshore that were generated near the coast have a higher POC content in their interior than cyclones found offshore that were locally generated offshore (Figure 4a). The higher POC content for cyclones that were generated near the coast (as in Figures 3b-3d, where cyclone A had a higher POC content than cyclone B) may be related to the trapping and offshore transport of coastal water that is rich in POC or to local production as the eddy propagates offshore through the utilization of nutrients that were trapped near the coast at formation (Amos et al., 2019). It may also be due to remineralization of the trapped POC and recycling into new carbon (and the associated nutrients that are also recycled along with the carbon), which would help maintain elevated POC concentrations as an eddy generated near the coast moves offshore (Amos et al., 2019). In all these cases, POC enrichment offshore is influenced by the trapping of coastal water and offshore transport by cyclonic eddies. In contrast, anticyclonic eddies are on average characterized by negative POC anomalies, and eddies generated offshore and those generated near the coast that propagated offshore are characterized by similar POC anomalies (Figure 4b). The differences observed between cyclones and anticyclones are likely related to the water that is trapped during formation. When a cyclone is formed along the boundary current flowing northeastward, it may trap coastal water rich in POC (e.g., cyclones A and D in Figure 3) and thus it may have a different POC content compared to a cyclone generated offshore (Figure 4a). An anticyclonic eddy, even if generated near the coast, will generally trap waters from the offshore side of the boundary current, which on average will have a lower POC content (e.g., anticyclone C, Figure 3). Thus, anticyclones generally have similar POC anomalies when they are found offshore, irrespectively of the generation location (Figure 4b). 

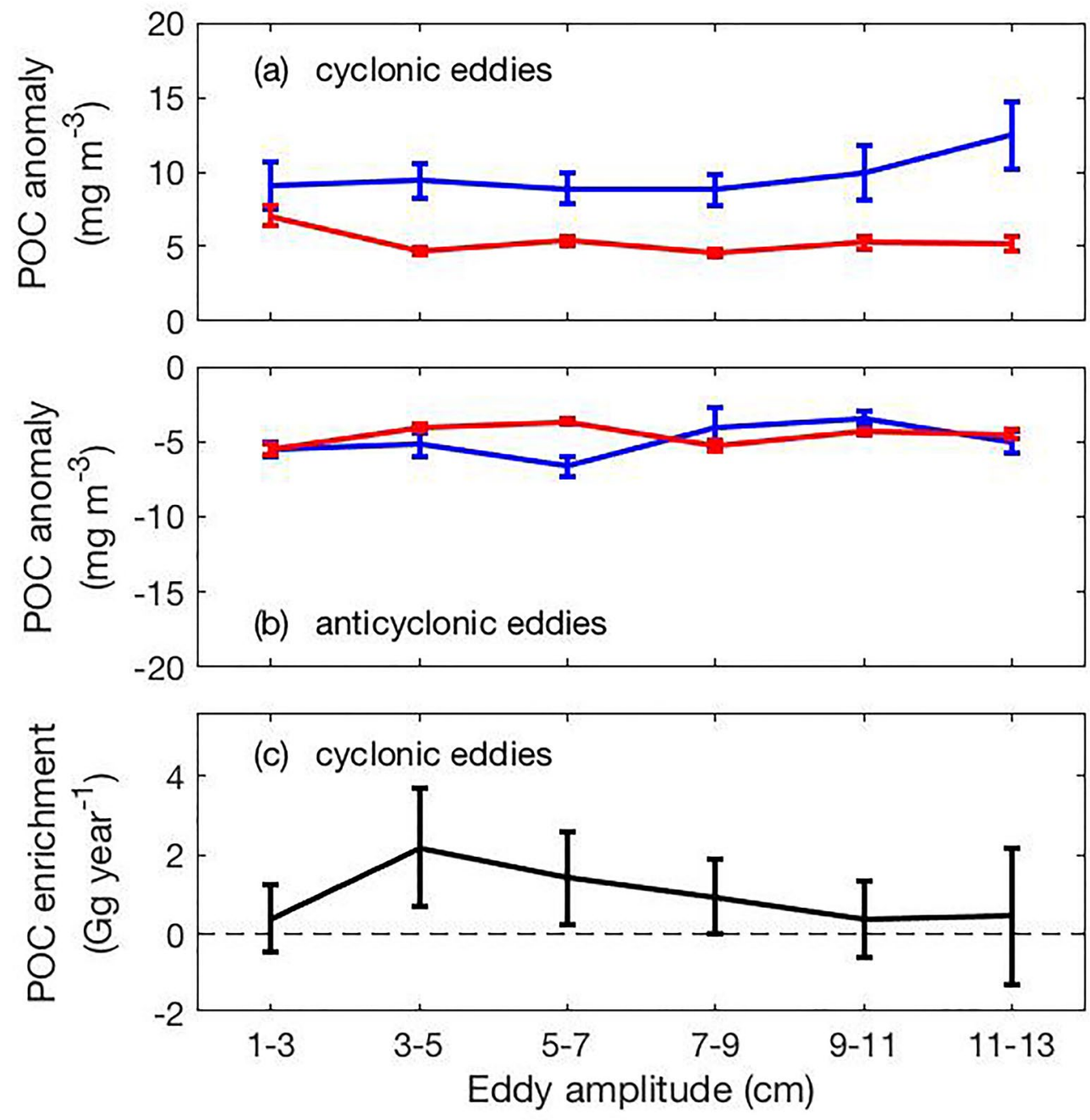

Figure 4. Mean POC anomaly and standard error within one eddy radius associated with (a) cyclonic and (b) anticyclonic eddies of different amplitudes found in the offshore region (see Figure 1) that were locally generated offshore (red) or generated near the coast and propagated offshore (blue). (c) POC enrichment and standard error in the offshore region due to cyclonic eddies generated near the coast that propagated offshore off the WAP. Total POC enrichment integrated across the various amplitude bins is $5.7 \pm 3.0 \mathrm{Gg} \mathrm{year}^{-1}$. POC, particulate organic carbon; WAP, West Antarctic Peninsula.

We used the number of cyclonic eddies generated near the coast that propagated offshore for different amplitude bins and the POC enhancement in the interior of those eddies (as in Figure 4a, but for the integrated POC content from the surface to $100 \mathrm{~m}-\mathrm{POC}_{100}$ ) to compute the POC enrichment in the offshore region due to eddy-driven transport using Equation 1. Our calculations revealed that offshore propagation of nonlinear cyclonic eddies across the southernmost transect shown in Figure 1 resulted in a POC enrichment of $5.7 \pm 3.0 \mathrm{Gg} \mathrm{C}$ year $^{-1}$ in offshore waters off the WAP (Figure 4c).

Most eddies off Antarctica between $65^{\circ}-60^{\circ} \mathrm{S}$ have a radius of $20-50 \mathrm{~km}$, peaking at about $30 \mathrm{~km}$ (Frenger et al., 2015). The eddies detected by altimetry that were generated near the coast and moved offshore off the WAP were slightly larger, with radii of about $40-60 \mathrm{~km}$ on average (Figures $5 \mathrm{a}$ and $5 \mathrm{~b}$ ). The smallest eddies identified moving offshore had radii of about $35 \mathrm{~km}$. This lower limit is likely influenced by limitations on the resolution capability of altimetry observations, which are unable to resolve features with e-folding scales smaller than about $0.4^{\circ}$ (Chelton, Schlax, \& Samelson, 2011). On average, 5.1 \pm 2.1 eddies were generated per year near the coast and moved offshore, with values for individual years varying between 2 and 12 . 

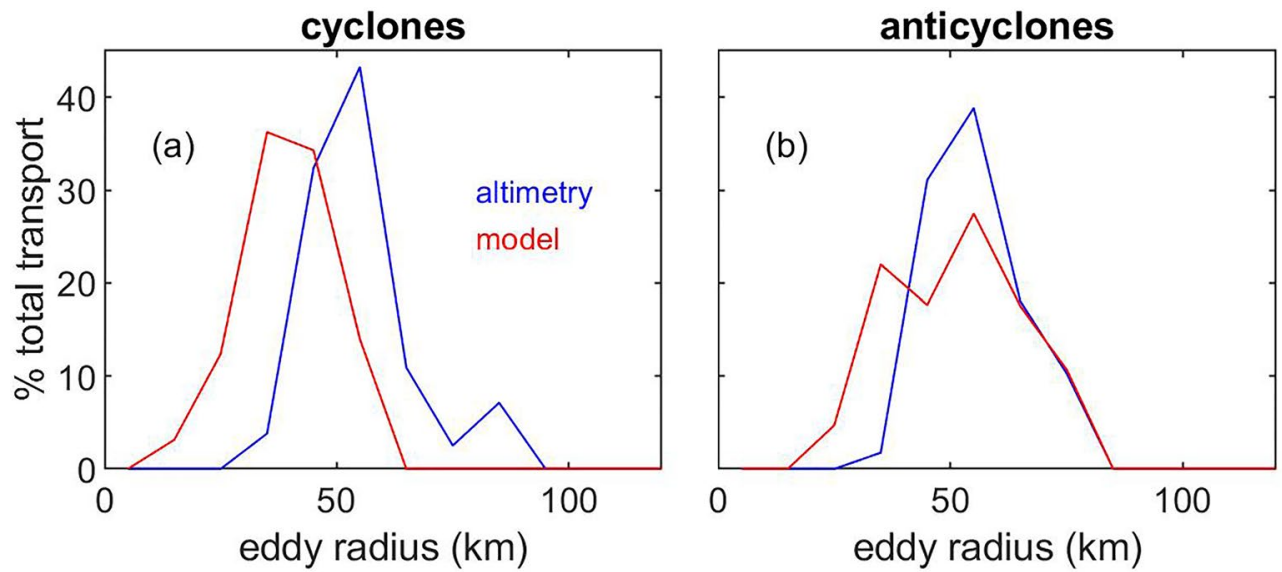

Figure 5. Fraction of volume transport due to (a) cyclonic and (b) anticyclonic eddies generated near the coast that propagated offshore (see Figure 1), as a function of eddy radius. Results are presented as percentage because they are not meant to provide a quantitative estimate of transport. Rather, the calculation is meant to quantify the relative contribution of eddies of different radii to total transport.

The potential contribution of smaller eddies to offshore transport was quantified using results from a high-resolution model simulation. The modeled fields showed that cyclonic eddies are often generated near the coast off the Peninsula (Figure 6). The simultaneous release of a passive tracer revealed that these cyclonic eddies can trap coastal water in their interior and transport it offshore as they move away from the coast (e.g., cyclonic eddy A on Figure 7), which is consistent with observations (Figure 3). However, the size distribution of the nonlinear eddies generated near the coast that move offshore (across the southernmost blue line in Figure 1) contributing to transport is different than in the observations. The cyclonic eddies are smaller in the model than in the observations, with an average radius of 30-50 km (Figure 5a). The smallest identified cyclone transporting coastal water offshore had a radius of $11 \mathrm{~km}$. Approximately $50 \%$ of the cyclonic eddy-driven modeled transport of coastal water occurs for eddies with radius $<40 \mathrm{~km}$, which are mostly missed by altimetry. For anticyclones, the difference in the size of modeled and observed eddies is smaller (Figure 5b). Most of the transport in the model occurs for eddies with a radius of 30-70 km, with the smallest anticyclone transporting coastal water offshore having a radius of $23 \mathrm{~km}$. About $25 \%$ of the anticyclonic eddy-driven transport occurs for eddies with radius $<40 \mathrm{~km}$. The number of eddies generated near the coast that moved offshore ranged between 5 and 10 year $^{-1}$ in the model simulations, with most of the eddies moving offshore between $66^{\circ}$ and $59^{\circ} \mathrm{W}$.

\section{Discussion}

Mesoscale eddies contribute important horizontal heat and salt transports on a global scale, mainly due to individual eddy movements (Dong et al., 2014). Nonlinear eddies, those with rotational speed $U$ exceeding their translation speed $c$, can trap fluid in their interior during formation (Flierl, 1981), potentially transporting the trapped water and its properties for large distances (Early et al., 2011; Lehahn et al., 2011). In high latitudes, where propagation speeds of eddies are reduced (Chelton et al., 2007; Chelton, Schlax, \& Samelson, 2011) contributing to increased $U / c$ ratios, trapping may be particularly important. Several previous studies have investigated eddy characteristics and dynamics in the Southern Ocean. These studies often focused on the region around and to the north of the ACC (Frenger et al., 2015), having addressed the role of mesoscale eddies in the transport of heat and biogeochemical tracers across the fronts of the ACC (Dufour et al., 2015) and revealing that eddies often have biological composition which is typical for the region where the eddy originated (Ansorge et al., 2009). In the ACC region, where eddies exhibit high swirl velocities, more than $90 \%$ of the variance of SST anomalies due to eddies can be related to trapping (Frenger et al., 2015).

Here, we focused on eddy-driven transport in the coastal region off the WAP. Even though the number of eddies decreases quickly close to the coast, the gradient in biogeochemical properties between coastal and 


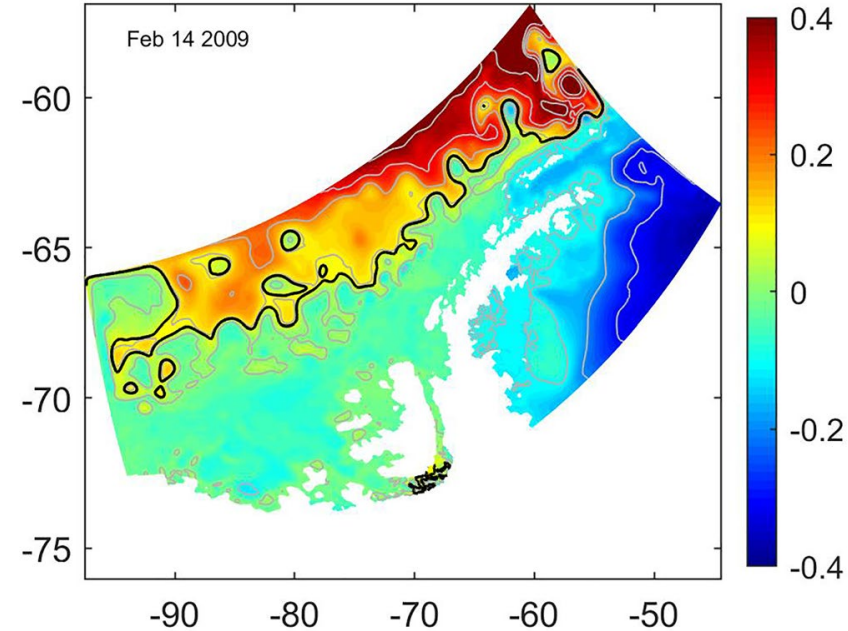

Figure 6. High-resolution ocean model domain. Colors show sea surface elevation (in meters) on February 14, 2009, 20 days after the model dye is released (see Figure 7). The $0.08 \mathrm{~m}$ contour is shown in black. Note formation of a cyclonic eddy at $62^{\circ} \mathrm{W}, 60.5^{\circ} \mathrm{S}$. offshore waters is large (Allison et al., 2010) indicating a potential for eddy-driven transport of biogeochemical signatures. Our observationally based analyses revealed that cyclonic eddies can indeed trap coastal water rich in POC and transport it offshore. As a result, cyclonic eddies generated near the coast that propagated offshore have on average double the POC anomaly compared to cyclonic eddies of similar amplitude generated locally offshore. This leads to a POC enrichment of almost $6 \mathrm{Gg} \mathrm{C}_{\text {year }}{ }^{-1}$ in offshore waters off the Peninsula, although as discussed below this likely represents an underestimation of the true impact of coastally generated eddies on the distribution of $\mathrm{POC}$ in offshore regions. These cyclones propagate on average $126 \pm 70 \mathrm{~km}(127 \pm 91 \mathrm{~km}$ in the model simulations) before becoming undetectable. This propagation distance is on the high end of the range of 10-100 km previously observed in the Southern Ocean (Frenger et al., 2015). Eddy suppression in the Southern Ocean is often due to the shear associated with its strong currents (Naveira Garabato et al., 2011; Thompson \& Sallée, 2012). Thus, eddies generated far from the ACC near the coast can propagate comparatively larger distances before being suppressed in the ACC region. Once cyclonic eddies are suppressed around the ACC, the coastal water that was trapped in their interior is presumably released into a region of strong currents that circumnavigate the globe, potentially spreading that biogeochemical signature (POC and any other material contained in the coastal water) toward different ocean basins.

Given the uncertainties in carbon fluxes in the Southern Ocean (Kessler \& Tjiputra, 2016; Hauck et al., 2020), it is difficult to estimate if the POC enrichment in offshore waters due to eddy-driven transport could be an important component of the carbon budget in the region. Considering the relatively small number of eddies detected by altimetry that are generated near the coast and move offshore, the contribution is likely small compared to the POC stock offshore. However, POC anomalies due to the trapping mechanism for the eddy composites (difference between blue and red lines in Figure 4a; about $5 \mathrm{mg} \mathrm{m}^{-3}$ )
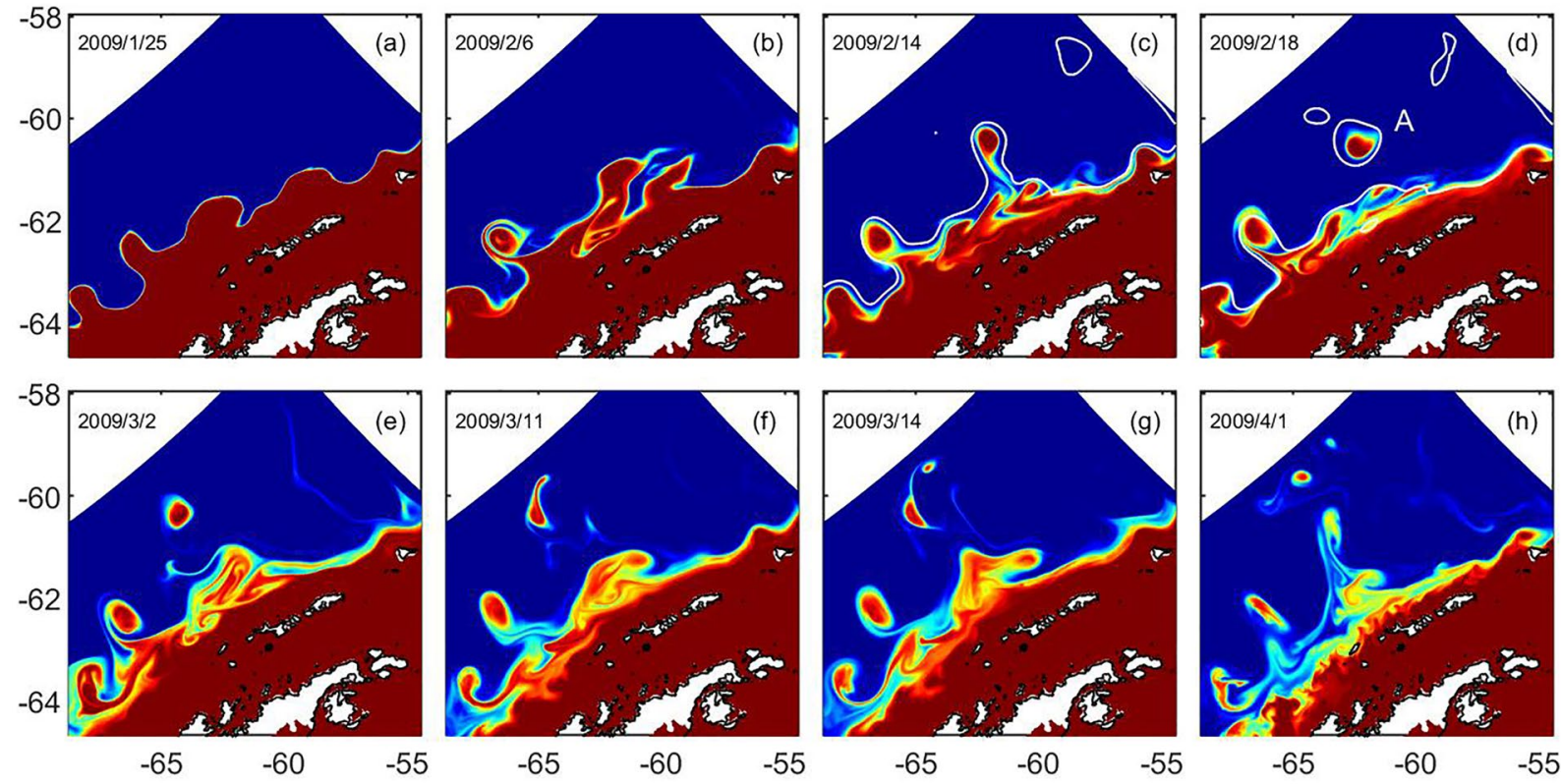

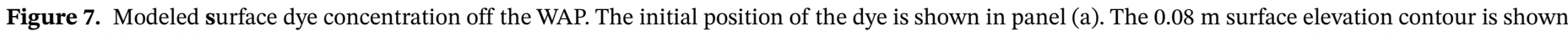
in panels (c) and (d) to highlight the formation of cyclonic eddy A. A larger view of the surface elevation field for February 14, 2009 (panel c) is shown in Figure 6. WAP, West Antarctic Peninsula. 
and for individual eddy occurrences (e.g., comparing eddies A and B in Figure 3; >50-60 $\mathrm{mg} \mathrm{m}^{-3}$ ) are comparable to total POC variability in offshore regions (spatial variability in area between blue lines in Figure 1 is $5-20 \mathrm{mg} \mathrm{m}^{-3}$ ). This suggest that eddy trapping and transport can be an important component driving local POC variability offshore, even if the contribution to the total POC stock is small. This is consistent with results for the California Current System (CCS), where eddies have been shown to provide the key mechanism for long-range transport of nutrients and organic matter from the coast into the offshore environment (Nagai et al., 2015). Using the same method used here, Amos et al. (2019) estimated the eddy-driven POC enrichment in offshore regions in the CCS to be $20.9 \pm 11 \mathrm{Gg}^{\text {year }}{ }^{-1}$, larger but of the same order of magnitude of the transport estimated here for the WAP. Amos et al. (2019) also showed that eddy trapping and transport results in an increase in POC anomalies associated with cyclonic eddies offshore in the CCS of $\sim 50 \%$. This relative increase is about half of that observed off the WAP, where the increase is $\sim 100 \%$ (Figure $4 \mathrm{a}$ ).

Regardless of how important eddy transport is to the POC budget, the composition of the POC transported offshore by cyclonic eddies is likely different than the composition of the POC found offshore, which may have important ecological implications. This is because coastal waters trapped during eddy formation are influenced by recent coastal production, which is known to add labile compounds to the carbon pool (Ahlgren et al., 1992; Medeiros et al., 2012), including saccharides and low molecular weight fatty acids (Medeiros et al., 2015). As the fresh material is transported offshore (e.g., Alonso-González et al., 2013; Álvarez-Salgado et al., 2001), it provides a pathway for coastal production to help support heterotrophic microorganisms away from the coast. Thus, growth conditions inside cyclonic eddies generated near the coast are likely different than those in surrounding waters. This can possibly drive changes in microbial community composition (Doherty et al., 2017), since activity by microorganisms has been shown to vary strongly as a function of POC quantity and composition (Satinsky et al., 2014). The degradation state of the organic matter transported within eddies may also influence particle settling velocities (Alonso-González et al., 2013), which influences the depth of organic matter decomposition and potential for carbon sequestration. Cyclonic eddies have been found to enhance organic carbon, amino acid, and pigment export in the Canary Current System with respect to noneddy conditions (Alonso-González et al., 2013). Microbial respiratory activity in that system has also been shown to be controlled by fluctuations in POC advected from productive coastal waters, in part due to mesoscale eddies (Arístegui et al., 2020). Our analyses off the WAP also serve as an indicator of transport of other quantities that cannot be easily measured by satellites, such as freshwater from ice melting, nutrients, and dissolved organic carbon.

As mentioned above, our calculation of POC enrichment in offshore regions likely represents an underestimation of the true impact of eddies due to several limitations in the data sets. Our high-resolution model results suggest that about half of the volume transport of near surface coastal water due to trapping by cyclones may occur for small eddies that are missed by altimetry observations. This is consistent with Brearley et al. (2019), who have shown that small scale eddies contribute to the export of cold shelf water to the open ocean off the Peninsula. Future satellite missions that will provide sea level anomalies in higher resolution (e.g., NASA's Surface Water and Ocean Topography mission-SWOT; Fu et al., 2012) will allow for investigating transport of coastal water rich in POC by small eddies based on observations. Using SWOT data in conjunction with high resolution ocean color observations will also allow for identifying POC anomalies associated with small scale eddies, a necessary step for quantifying POC enrichment in offshore regions due to submesoscale eddies. Additionally, only eddies with a lifespan of at least 4 weeks were retained in our analyses to reduce noise (Chelton, Schlax, \& Samelson, 2011), but short-lived features may also be significant (Brearley et al., 2019) especially given that eddies propagate only $O(100) \mathrm{km}$ before being suppressed in the ACC region. Last, satellite-derived POC measurements were obtained based on an algorithm calibrated for open waters (Allison et al., 2010), which possibly underestimates in situ content in POC-rich coastal regions off the WAP (Figure 2). Collectively, these limitations suggest that our calculations may substantially underestimate POC enrichment offshore due to eddy-driven transport. Despite these limitations, our observationally based analyses demonstrate that eddy trapping of coastal water and offshore transport of the trapped material is significant enough to alter the average distribution of properties inside cyclonic eddies in offshore regions. Future modeling studies including a biogeochemical component can contribute to reducing uncertainty in the estimates by fully capturing the importance of small-scale eddies. 
Satellite-based estimates of eddy-driven volume transport associated with trapping are dependent on estimates of the trapping depth (generally determined using Argo observations; Castelao, 2014; Chaigneau et al., 2011) and trapping efficiency (Amos et al., 2019; Donners \& Drijfhout, 2004; Nakano et al., 2013). We chose not to quantitatively estimate volume transport by eddies because few Argo profiles are available near the coast, not allowing for robust estimates of the trapping depth. Instead, we only estimated the fraction of volume transport that is due to eddies of different radii (Figure 5) in a given surface layer shallower than the minimum trapping depth for the eddies of different sizes, assuming that the trapping efficiency is approximately the same for eddies of different radii, as has been done previously in other settings (Castelao, 2014; Sangrà et al., 2009). In the CCS, the variation in trapping efficiency between different eddies is around $10 \%$ (Amos et al., 2019), suggesting that the uncertainty introduced in the calculation due to this assumption is small (volume transport scales linearly with trapping efficiency). Although these assumptions precluded quantitative estimates of eddy-driven volume transport, they allowed for using our high-resolution model results to identify that small-scale eddies that are missed by satellite observations have the potential to account for half of the total eddy-driven volume transport off the WAP. We note that our estimate of POC enrichment offshore due to eddy-driven transport (Figure 4c) based on observations is not dependent on estimates of the trapping depth or trapping efficiency (Equation 1; Amos et al., 2019). Furthermore, by integrating the higher-resolution POC data spatially within the eddy, the effects of possible smoothing of sea level anomalies and uncertainties in eddy size determined by low-resolution altimetry data are minimized. When the eddy scale determined by altimetry is larger than the scale of the POC anomaly (e.g., cyclone A in Figure 3f), the spatially integrated POC anomaly within the eddy is not strongly influenced by that, since the POC anomaly near the outer boundaries of the eddy (as identified by altimetry) is close to zero.

Our analyses were focused on the WAP because it extends into lower latitudes, allowing for better altimetry coverage and less sea-ice cover. However, mesoscale eddies are ubiquitous features in the Southern Ocean (Patara et al., 2016) and POC accumulation during summer is also observed in several other Antarctic coastal regions (Allison et al., 2010). These suggest that offshore transport of coastal water rich in POC by nonlinear eddies could be important throughout Antarctica, which would result in substantially larger offshore transport of POC and other material contained in the trapped water, including fresh components associated with recent coastal production (Álvares-Salgado et al., 2001; Medeiros et al., 2015) that have a large potential to influence ecological processes offshore (Doherty et al., 2017; Satinsky et al., 2014). The Indian Ocean sector of the Southern Ocean may be a good region for this process to be investigated, given the northward extent of the coastline into latitudes where altimetry observations are more readily available.

\section{Data Availability Statement}

Observations are available at www.aviso.altimetry.fr (global mesoscale eddy trajectory product), https:// resources.marine.copernicus.eu/?option=com_csw\&task=results (SEALEVEL_GLO_PHY_CLIMATE_ L4_REP_OBSERVATIONS_008_057), https://oceandata.sci.gsfc.nasa.gov/SeaWiFS (daily, 9 km, Rrs_443, and Rrs_555), and https://pal.lternet.edu/data (Organic Matter, Particulate Organic Carbon and Nitrogen, cruise and station). Model codes are available at www.myroms.org Model outputs used for this analysis are available at BCO-DMO (https://www.bco-dmo.org/dataset/831045).

\footnotetext{
Acknowledgments

The authors thank the three anonymous reviewers for their constructive comments and suggestions, which resulted in an improved manuscript. The authors gratefully acknowledge support by NSF (OPP-1643468 to UGA and OPP-1643386 to ODU) and NASA Physical Oceanography (80NSSC18K0766).
}

\section{References}

Ahlgren, G., Gustafsson, I.-B., \& Boberg, M. (1992). Fatty acid content and chemical composition of freshwater Microalgae1. Journal of Phycology, 28, 37-50. https://doi.org/10.1111/j.0022-3646.1992.00037.x

Allison, D. B., Stramski, D., \& Mitchell, B. G. (2010). Seasonal and interannual variability of particulate organic carbon within the Southern Ocean from satellite ocean color observations. Journal of Geophysical Research, 115, C06002. https://doi.org/10.1029/2009JC005347

Alonso-González, I. J., Arístegui, J., Lee, C., Sanchez-Vidal, A., Calafat, A., Fabrés, J., et al. (2013). Carbon dynamics within cyclonic eddies: Insights from a biomarker study. PLoS ONE, 8(12), e82447. https://doi.org/10.1371/journal.pone.0082447

Álvarez-Salgado, X. A., Doval, M. D., Borges, A. V., Joint, I., Frankignoulle, M., Woodward, E. M. S., \& Figueiras, F. G. (2001). Off-shelf fluxes of labile materials by an upwelling filament in the NW Iberian upwelling system. Progress in Oceanography, 51, 321-337. https:// doi.org/10.1016/s0079-6611(01)00073-8

Amos, C. M., Castelao, R. M., \& Medeiros, P. M. (2019). Offshore transport of particulate organic carbon in the California current system from mesoscale eddies. Nature Communications, 10, 4960. https://doi.org/10.1038/s41467-019-12783-5

Ansorge, I. J., Pakhomov, E. A., Kaehler, S., Lutjeharms, J. R. E., \& Durgadoo, J. V. (2009). Physical and biological coupling in eddies in the lee of the South-West Indian ridge. Polar Biology, 33(6), 747-759. https://doi.org/10.1007/s00300-009-0752-9 
Arístegui, J., Montero, M. F., Hernández-Hernández, N., Alonso-González, I. J., Baltar, F., Calleja, M. L., \& Duarte, C. M. (2020). Variability in water-column respiration and its dependence on organic carbon sources in the Canary Current upwelling region. Frontiers of Earth Science, 8, 349. https://doi.org/10.3389/feart.2020.00349

Brearley, J. A., Moffat, C., Venables, H. J., Meredith, M. P., \& Dinniman, M. S. (2019). The role of eddies and topography in the export of shelf waters from the west Antarctic Peninsula shelf. Journal of Geophysical Research: Oceans, 124, 7718-7742. https://doi. org/10.1029/2018JC014679

Budgell, W. P. (2005). Numerical simulation of ice-ocean variability in the Barents Sea region. Ocean Dynamics, 55, 370-387. https://doi. org/10.1007/s10236-005-0008-3

Castelao, R. M. (2014). Mesoscale eddies in the South Atlantic Bight and the Gulf Stream recirculation region: Vertical structure. Journal of Geophysical Research: Oceans, 119, 2048-2065. https://doi.org/10.1002/2014JC009796

Castelao, R. M., \& He, R. (2013). Mesoscale eddies in the South Atlantic Bight. Journal of Geophysical Research: Oceans, 118, 5720-5731. https://doi.org/10.1002/jgrc.20415

Chaigneau, A., Le Texier, M., Eldin, G., Grados, C., \& Pizarro, O. (2011). Vertical structure of mesoscale eddies in the eastern South Pacific Ocean: A composite analysis from altimetry and argo profiling floats. Journal of Geophysical Research, 116, C11025. https://doi. $\operatorname{org} / 10.1029 / 2011 \mathrm{JC} 007134$

Chelton, D. B., Gaube, P., Schlax, M. G., Early, J. J., \& Samelson, R. M. (2011). The influence of nonlinear mesoscale eddies on near-surface oceanic chlorophyll. Science, 334, 328-332. https://doi.org/10.1126/science.1208897

Chelton, D. B., Schlax, M. G., Freilich, M. H., \& Milliff, R. F. (2004). Satellite measurements reveal persistent small-scale features in ocean winds. Science, 303, 978-983. https://doi.org/10.1126/science.1091901

Chelton, D. B., Schlax, M. G., \& Samelson, R. M. (2011). Global observations of nonlinear mesoscale eddies. Progress in Oceanography, 91 , 167-216. https://doi.org/10.1016/j.pocean.2011.01.002

Chelton, D. B., Schlax, M. G., Samelson, R. M., \& de Szoeke, R. A. (2007). Global observations of large oceanic eddies. Geophysical Research Letters, 34, L15606. https://doi.org/10.1029/2007GL030812

Chenillat, F., Franks, P. J. S., \& Combes, V. (2016). Biogeochemical properties of eddies in the California Current System. Geophysical Research Letters, 43, 5812-5820. https://doi.org/10.1002/2016GL068945

Couto, N., Martinson, D. G., Kohut, J., \& Schofield, O. (2017). Distribution of upper circumpolar deep water on the warming continental shelf of the West Antarctic Peninsula. Journal of Geophysical Research: Oceans, 122, 5306-5315. https://doi.org/10.1002/2017JC012840

de Steur, L., van Leeuwen, P. J., \& Drijfhout, S. S. (2004). Tracer leakage from modeled Agulhas Rings. Journal of Physical Oceanography, 34, 1387-1399. https://doi.org/10.1175/1520-0485(2004)034<1387:tlfmar>2.0.co;2

Dinniman, M. S., Klinck, J. M., \& Smith, W. O. (2011). A model study of circumpolar deep water on the West Antarctic Peninsula and Ross Sea continental shelves. Deep Sea Research Part II: Topical Studies in Oceanography, 58, 1508-1523. https://doi.org/10.1016/j. dsr2.2010.11.013

Doherty, M., Yager, P. L., Moran, M. A., Coles, V. J., Fortunato, C. S., Krusche, A. V., et al. (2017). Bacterial biogeography across the Amazon river-ocean continuum. Frontiers in Microbiology, 8, 882. https://doi.org/10.3389/fmicb.2017.00882

Dong, C., McWilliams, J. C., Liu, Y., \& Chen, D. (2014). Global heat and salt transports by eddy movement. Nature Communications, 5 , 3294. https://doi.org/10.1038/ncomms4294

Donners, J., \& Drijfhout, S. (2004). Impact of cooling on the water mass exchange of Agulhas rings in a high resolution ocean model. Geophysical Research Letters, 31, L16312. https://doi.org/10.1029/2004GL020644

Dufour, C. O., Griffies, S. M., de Souza, G. F., Frenger, I., Morrison, A. K., Palter, J. B., et al. (2015). Role of mesoscale eddies in cross-frontal transport of heat and biogeochemical tracers in the Southern Ocean. Journal of Physical Oceanography, 45, 3057-3081. https://doi. org/10.1175/jpo-d-14-0240.1

Early, J. J., Samelson, R. M., \& Chelton, D. B. (2011). The evolution and propagation of quasigeostrophic ocean eddies. Journal of Physical Oceanography, 41, 1535-1555. https://doi.org/10.1175/2011JPO4601.1

Flierl, G. R. (1981). Particle motions in large-amplitude wave fields. Geophysical \& Astrophysical Fluid Dynamics, 18(1-2), 39-74. https:// doi.org/10.1080/03091928108208773

Frenger, I., Gruber, N., Knutti, R., \& Münnich, M. (2013). Imprint of Southern Ocean eddies on winds, clouds and rainfall. Nature Geoscience, 6, 608-612. https://doi.org/10.1038/ngeo1863

Frenger, I., Münnich, M., Gruber, N., \& Knutti, R. (2015). Southern Ocean eddy phenomenology. Journal of Geophysical Research: Oceans, 120, 7413-7449. https://doi.org/10.1002/2015JC011047

Fretwell, P., Pritchard, H. D., Vaughan, D. G., Bamber, J. L., Barrand, N. E., Bell, R.R., et al. (2013). Bedmap2: Improved ice bed, surface and thickness datasets for Antarctica. The Cryosphere, 7(1), 375-393. https://doi.org/10.5194/tc7-375-201310.5194/tc-7-375-2013

Fu, L.-L., Alsdorf, D., Morrow, R., Rodriguez, E., \& Mognard, N. (2012). SWOT: The surface water and ocean topography mission - Wideswath altimetric measurement of water elevation on Earth. NASA. Retrieved from https://trs.jpl.nasa.gov/handle/2014/41996

Gardner, W. D., Mishonov, A. V., \& Richardson, M. J. (2006). Global POC concentrations from in-situ and satellite data. Deep Sea Research Part II: Topical Studies in Oceanography, 53, 718-740. https://doi.org/10.1016/j.dsr2.2006.01.029

Gaube, P., Chelton, D. B., Strutton, P. G., \& Behrenfeld, M. J. (2013). Satellite observations of chlorophyll, phytoplankton biomass, and Ekman pumping in nonlinear mesoscale eddies. Journal of Geophysical Research: Oceans, 118, 6349-6370. https://doi. org/10.1002/2013JC009027

Gaube, P., McGillicuddy, D. J., Jr., Chelton, D. B., Behrenfeld, M. J., \& Strutton, P. G. (2014). Regional variations in the influence of mesoscale eddies on near-surface chlorophyll. Journal of Geophysical Research: Oceans, 119, 8195-8220. https://doi.org/10.1002/2014JC010111

Gaube, P., McGillicuddy, D. J., Jr., \& Moulin, A. J. (2019). Mesoscale eddies modulate mixed layer depth globally. Geophysical Research Letters, 46, 1505-1512. https://doi.org/10.1029/2018gl080006

Graham, J. A., Dinniman, M. S., \& Klinck, J. M. (2016). Impact of model resolution for on-shelf heat transport along the West Antarctic Peninsula. Journal of Geophysical Research: Oceans, 121, 7880-7897. https://doi.org/10.1002/2016JC011875

Haidvogel, D. B., Arango, H., Budgell, W. P., Cornuelle, B. D., Curchitser, E., Di Lorenzo, E., et al. (2008). Ocean forecasting in terrain-following coordinates: Formulation and skill assessment of the regional ocean modeling system. Journal of Computational Physics, 227, 3595-3624. https://doi.org/10.1016/j.jcp.2007.06.016

Haidvogel, D. B., \& Beckmann, A. (1999). Numerical Ocean Circulation Modeling. London: Imperial College Press, 318 pp.

Hauck, J., Zeising, M., Le Quéré, C., Gruber, N., Bakker, D. C. E., Bopp, L., et al. (2020). Consistency and challenges in the ocean carbon sink estimate for the global carbon budget. Frontiers in Marine Science, 7, 571720. https://doi.org/10.3389/fmars.2020.571720

Holland, D. M., Jenkins, A. (1999). Modeling thermodynamic ice-ocean interactions at the base of an ice shelf. Journal of Physical Oceanography, 29(8), 1787-1800. https://doi.org/10.1175/1520-0485(1999)029<1787:MTIOIA>2.0.CO;2 
Kahru, M., Mitchell, B. G., Gille, S. T., Hewes, C. D., \& Holm-Hansen, O. (2007). Eddies enhance biological production in the Weddell-Scotia confluence of the Southern Ocean. Geophysical Research Letters, 34, L14603. https://doi.org/10.1029/2007GL030430

Kessler, A., \& Tjiputra, J. (2016). The Southern Ocean as a constraint to reduce uncertainty in future ocean carbon sinks. Earth System Dynamics, 7, 295-312. https://doi.org/10.5194/esd-7-295-2016

Lehahn, Y., d'Ovidio, F., Lévy, M., Amitai, Y., \& Heifetz, E. (2011). Long range transport of a quasi isolated chlorophyll patch by an Agulhas ring. Geophysical Research Letters, 38, L16610. https://doi.org/10.1029/2011GL048588

Luria, C. M., Amaral-Zettler, L. A., Ducklow, H. W., Repeta, D. J., Rhyne, A. L., \& Rich, J. J. (2017). Seasonal shifts in bacterial community responses to phytoplankton-derived dissolved organic matter in the Western Antarctic Peninsula. Frontiers in Microbiology, 8, 2117. https://doi.org/10.3389/fmicb.2017.02117

Martinson, D. G., \& McKee, D. C. (2012). Transport of warm upper circumpolar deep water onto the western Antarctic Peninsula continental shelf. Ocean Science, 8, 433-442. https://doi.org/10.5194/os-8-433-2012

McKee, D. C., Martinson, D. G., \& Schofield, O. (2019). Origin and attenuation of mesoscale structure in circumpolar deep water intrusions to an Antarctic shelf. Journal of Physical Oceanography, 49, 1293-1318. https://doi.org/10.1175/JPO-D-18-0133.1

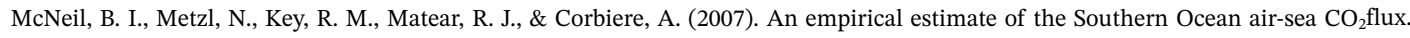
Global Biogeochemical Cycles, 21, GB3011. https://doi.org/10.1029/2007GB002991

Medeiros, P. M., Seidel, M., Ward, N. D., Carpenter, E. J., Gomes, H. R., Niggemann, J., et al. (2015). Fate of the Amazon River dissolved organic matter in the tropical Atlantic Ocean. Global Biogeochemical Cycles, 29, 677-690. https://doi.org/10.1002/2015GB005115

Medeiros, P. M., Sikes, E. L., Thomas, B., \& Freeman, K. H. (2012). Flow discharge influences on input and transport of particulate and sedimentary organic carbon along a small temperate river. Geochimica et Cosmochimica Acta, 77, 317-334. https://doi.org/10.1016/j. gca.2011.11.020

Metzl, N., Tilbrook, B., \& Poisson, A. (1999). The annual fCO2 cycle and the air-sea CO2 flux in the sub-Antarctic Ocean. Tellus B: Chemical and Physical Meteorology, 51, 849-861. https://doi.org/10.1034/j.1600-0889.1999.t01-3-00008.x

Moffat, C., Owens, B., \& Beardsley, R. C. (2009). On the characteristics of circumpolar deep water intrusions to the west Antarctic Peninsula continental shelf. Journal of Geophysical Research, 114, C05017. https://doi.org/10.1029/2008JC004955

Nagai, T., Gruber, N., Frenzel, H., Lachkar, Z., McWilliams, J. C., \& Plattner, G.-K. (2015). Dominant role of eddies and filaments in the offshore transport of carbon and nutrients in the California current system. Journal of Geophysical Research: Oceans, 120, 5318-5341. https://doi.org/10.1002/2015JC010889

Nakano, H., Tsujino, H., \& Sakamoto, K. (2013). Tracer transport in cold-core rings pinched off from the Kuroshio Extension in an eddy-resolving ocean general circulation model. Journal of Geophysical Research: Oceans, 118, 5461-5488. https://doi.org/10.1002/jgrc.20375

Naveira Garabato, A. C., Ferrari, R., \& Polzin, K. L. (2011). Eddy stirring in the Southern Ocean. Journal of Geophysical Research, 116, C09019. https://doi.org/10.1029/2010JC006818

Pabi, S., \& Arrigo, K. R. (2006). Satellite estimation of marine particulate organic carbon in waters dominated by different phytoplankton taxa. Journal of Geophysical Research, 111, C09003. https://doi.org/10.1029/2005JC003137

Patara, L., Böning, C. W., \& Biastoch, A. (2016). Variability and trends in Southern Ocean eddy activity in $1 / 12^{\circ}$ ocean model simulations. Geophysical Research Letters, 43, 4517-4523. https://doi.org/10.1002/2016GL069026

Powers, J. G., Manning, K. W., Bromwich, D. H., Cassano, J. J., \& Cayette, A. M. (2012). A decade of Antarctic science support through AMPS. Bulletin of the American Meteorological Society, 93(11), 1699-1712. https://doi.org/10.1175/BAMS-D-11-00186.1

Samelson, R. M., Schlax, M. G., \& Chelton, D. B. (2014). Randomness, symmetry, and scaling of mesoscale eddy life cycles. Journal of Physical Oceanography, 44, 1012-1029. https://doi.org/10.1175/jpo-d-13-0161.1

Samelson, R. M., \& Wiggins, S. (2006). Lagrangian Transport in Geophysical Jets and Waves: The Dynamical Systems Approach. New York, NY: Springer. .

Sangrà, P., Pascual, A., Rodríguez-Santana, Á., Machín, F., Mason, E., McWilliams, J. C., et al. (2009). The canary eddy corridor: A major pathway for long-lived eddies in the subtropical North Atlantic. Deep Sea Research Part I: Oceanographic Research Papers, 56, $2100-2114$. https://doi.org/10.1016/j.dsr.2009.08.008

Satinsky, B. M., Crump, B. C., Smith, C. B., Sharma, S., Zielinski, B. L., Doherty, M., et al. (2014). Microspatial gene expression patterns in the Amazon River plume. Proceedings of the National Academy of Sciences, 111, 11085-11090. https://doi.org/10.1073/pnas.1402782111

Schlax, M. G., Chelton, D. B. (2016). The "growing method" of eddy identification and tracking in two and three dimensions. Retrieved from http://wombat.coas.oregonstate.edu/eddies/Growing_Method_of_Eddy_Identification_and_Tracking.pdf

Stewart, A. L., Klocker, A., \& Menemenlis, D. (2018). Circum-Antarctic shoreward heat transport derived from an eddy- and tide-resolving simulation. Geophysical Research Letters, 45, 834-845. https://doi.org/10.1002/GL07567710.1002/2017gl075677

Stramski, D., Reynolds, R. A., Babin, M., Kaczmarek, S., Lewis, M. R., Röttgers, R., et al. (2008). Relationships between the surface concentration of particulate organic carbon and optical properties in the eastern South Pacific and eastern Atlantic Oceans. Biogeosciences, 5, 171-201. https://doi.org/10.5194/bg-5-171-2008

Stramski, D., Reynolds, R. A., Kahru, M., \& Mitchell, B. G. (1999). Estimation of particulate organic carbon in the ocean from satellite remote sensing. Science, 285, 239-242. https://doi.org/10.1126/science.285.5425.239

Takahashi, T., Sutherland, S. C., Sweeney, C., Poisson, A., Metzl, N., Tilbrook, B., et al. (2002). Global sea-air $\mathrm{CO}_{2}$ flux based on climatological surface ocean $\mathrm{pCO}_{2}$, and seasonal biological and temperature effects. Deep Sea Research Part II: Topical Studies in Oceanography, 49, 1601-1622. https://doi.org/10.1016/S0967-0645(02)00003-6

Thompson, A. F., \& Sallée, J.-B. (2012). Jets and topography: Jet transitions and the impact on transport in the Antarctic Circumpolar Current. Journal of Physical Oceanography, 42, 956-972. https://doi.org/10.1175/JPO-D-11-0135.1

Yuan, Y., \& Castelao, R. M. (2017). Eddy-induced sea surface temperature gradients in Eastern Boundary Current Systems. Journal of Geophysical Research: Oceans, 122, 4791-4801. https://doi.org/10.1002/2017JC012735 